\title{
Effect of a joint policy statement by nine UK shooting and rural organisations on the use of lead shotgun ammunition for hunting common pheasants Phasianus colchicus in Britain
}

Rhys E. Green ${ }^{1,2^{*}+}$, Mark A. Taggart ${ }^{3+}$, Deborah J. Pain ${ }^{1+}$, Nigel A. Clark ${ }^{4}$, Louise Clewley ${ }^{5}$, Ruth Cromie ${ }^{6}$, Bob Elliot ${ }^{7}$, Ros M.W. Green ${ }^{4}$, Brian Huntley ${ }^{8}$, Jacqui Huntley ${ }^{9}$, Roderick Leslie ${ }^{10}$, Richard Porter ${ }^{11}$, James A. Robinson ${ }^{6}$, Ken W. Smith ${ }^{2}$, Linda Smith ${ }^{2}$, Jonathan Spencer ${ }^{12}$ \& David Stroud ${ }^{13}$ https://doi.org/10.52201/CEJ18ROTZ8607

${ }^{1}$ Department of Zoology, University of Cambridge, Downing Street, Cambridge CB2 3EJ, UK

${ }^{2}$ Centre for Conservation Science, RSPB, The Lodge, Sandy, Bedfordshire SG19 2 DL, UK

${ }^{3}$ Environmental Research Institute, University of the Highlands and Islands, Castle Street, Thurso KW14 7AP, UK

${ }^{4}$ British Trust for Ornithology, The Nunnery, Thetford, Norfolk IP24 2PU, UK

${ }^{5}$ Langleys Farm, Martin Lane, Burscough, Lancashire L4O ORU, UK

${ }^{6}$ Wildfowl \& Wetlands Trust, Slimbridge, Gloucestershire GL2 7BT, UK

${ }^{7}$ OneKind, 50 Montrose Terrace. Edinburgh EH7 5DL, UK

${ }^{8}$ Department of Biosciences, Durham University, South Road, Durham DH1 3LE, UK

${ }^{9}$ Department of Archaeology, Durham University, South Road, Durham DH1 3LE, UK

108 Somerset St, Bristol BS2 8NB, UK

${ }^{11}$ King's Head Cottage, Cley next the Sea, Norfolk NR25 7RX, UK

${ }^{12}$ Environmental Change Institute, Oxford University Centre for the Environment, South Parks Road, Oxford OX1 $3 Q Y, U K$

${ }^{13}$ Spring Meadows, Taylors Green, Warmington, Peterborough PE8 6TG, UK

\begin{abstract}
SUMMARY
There are significant negative effects of exposure to spent lead ammunition on wildlife and human health. A joint statement was issued by nine UK shooting and rural organisations on $24^{\text {th }}$ February 2020 intended to encourage a voluntary transition to non-lead shotgun ammunition within five years "in consideration of wildlife, the environment and to ensure a market for the healthiest game products". We dissected carcasses of wild-shot common pheasants Phasianus colchicus sold or offered for human consumption in Britain in the shooting season between $1^{\text {st }}$ October 2020 and $1^{\text {st }}$ February 2021 to recover shotgun pellets. The principal metallic element composing one pellet from each bird was identified using inductively coupled plasma atomic emission spectrometry. The results showed that $99 \%$ of the 180 pheasants from which shotgun pellets were recovered had been killed using lead shotgun ammunition, compared with $100 \%$ in a much smaller study conducted in the $2008 / 2009$ shooting season. We conclude that the shooting and rural organisations' joint statement, and their subsequent promotional actions, have not yet had a detectable effect on the ammunition types used by shooters supplying pheasants to the British game market.
\end{abstract}

\section{BACKGROUND}

Shooting of live quarry animals is a major activity in the UK, involving 380,000 people (PACEC 2014). Since the $18^{\text {th }}$ Century, lead has been the principal constituent of most of the shotgun pellets used for hunting birds and mammals under $10 \mathrm{~kg}$ body weight. Despite well-documented concerns about the toxicity of lead, shotgun ammunition composed principally of lead remains in widespread use in Europe, North America and elsewhere (Kanstrup \& Thomas 2019). There are significant negative effects of spent lead ammunition on wildlife (Pain et al. 2019) and on public health (Green \& Pain 2019). Common buzzards Buteo buteo in the UK are exposed to lead from shotgun pellets when feeding, particularly during the gamebird shooting season (Taggart et al. 2020). Isotope analysis indicated that

\footnotetext{
*corresponding author email address: reg29@cam.ac.uk these authors were the principal investigators and contributed equally to the study
}

$89 \%$ of the lead in livers of sampled dead buzzards with high liver concentrations of lead, consistent with acute exposure, came from shotgun pellets. Transition to the use of non-lead ammunition, which is defined by $\mathrm{UK}$ regulations as containing $<1 \%$ lead, has been attempted by a variety of means in different parts of the world, including encouragement of voluntary change, partial regulation of use for selected species and habitats (e.g. USA and 21 European countries; Mateo \& Kanstrup 2019) and full statutory bans on the sale, possession and use of lead shotgun ammunition for all types of shooting, including wild quarry and clay targets (e.g. Denmark; Mateo \& Kanstrup 2019). Organisations representing game shooting interests in the United Kingdom do not currently appear to support legal restrictions on the use of lead ammunition, beyond the existing bans in the four UK countries on the use of lead gunshot for shooting listed species, including ducks and geese, and/or in certain wetlands. In England, research has shown a 
continuing high level of non-compliance $(>70 \%)$ with the unenforced 1999 ban on lead ammunition for shooting wildfowl anywhere and over certain wetlands (Cromie et al. 2015).

As scientific evidence about the negative effects of lead ammunition has accumulated, and a wider range of types of non-lead shotgun ammunition has become available, the acceptability of lead as the shooters' ammunition of choice has declined. In 2016, the European Union (EU) began work on the first of two proposals to restrict the use of lead ammunition in the EU under its chemicals regulations (REACH). These restrictions are likely to impact markets in the EU of current importance for British game products. In July 2019, the supermarket Waitrose \& Partners announced its intention to move, in a phased way, to selling only wild game killed with non-lead ammunition (Barkham 2019). On 24 February 2020, nine UK shooting and rural organisations issued a joint statement expressing their collective wish to see an end, within five years, to both lead shotgun pellets and single-use plastic wads in ammunition used by those taking all live quarry with shotguns (BASC 2020a). The intention of these organisations is that this transition should proceed on a voluntary basis. The joint statement can therefore be regarded as an example of an attempt at voluntary control of harm, such as that caused to the environment or public health by a human activity. Recent UK governments have preferred voluntary controls to regulation, which it has been suggested should only be used as a last resort (National Audit Office 2014).

The aim of our study is to assess the short-term effect of the joint policy statement and follow-up actions as mechanisms to encourage voluntary change in the practices of hunters. In the UK, the most numerous quarry species killed using shotgun ammunition is the common pheasant Phasianus colchicus (PACEC 2014), so our study estimates the proportion of pheasants offered for human consumption in Britain that were shot with lead, rather than other shotgun pellet types, in the first shooting season ( $1^{\text {st }}$ October 2020 to $1^{\text {st }}$ February 2021) after the statement was issued. We compare this proportion with published results obtained from sampling pheasants in 2008/2009; 12 years before the statement was issued.

\section{ACTION}

Statement of intent to encourage voluntary phasing out of lead shotgun ammunition

On $24^{\text {th }}$ February 2020, a joint statement on the future of shotgun ammunition for live quarry shooting in the UK (BASC 2020a) was issued by nine UK shooting and rural organisations: the Game \& Wildlife Conservation Trust (GWCT); British Game Alliance; British Association for Shooting and Conservation (BASC); Countryside Alliance; Country Landowners' Association; The Moorland Association; The National Gamekeepers' Organisation; Scottish Land \& Estates; and the Scottish Association for Country Sports. It stated that "in consideration of wildlife, the environment and to ensure a market for the healthiest game products, at home and abroad, we wish to see an end to both lead and single-use plastics in ammunition used by those taking all live quarry with shotguns within five years". The joint statement was welcomed by the UK government department responsible for regulating the use of lead ammunition (Department for Environment, Food \& Rural Affairs) as a 'voluntary move which will bring benefits for wildlife and the wider environment' (DEFRA 2020).

The joint statement was placed on the websites of all of the signatory organisations. Most organisations also posted a frequently-askedquestions document or similar and a few posted advice on the use of non-lead ammunition. We cannot comment on whether additional information was available on the websites of organisations requiring member login for full access.

Efforts by shooting and rural organisations to promote voluntary phasing out of lead shotgun ammunition

BASC appears to have been the most active organisation in promoting the transition to non-lead shot. It has followed up on the joint statement by publishing articles on the phasing out of lead shotgun ammunition in each of the five issues of its magazine Shooting and Conservation published since the statement's release. The magazine is sent to all 150,000 BASC members. Regional and country BASC teams have briefed thousands of members and non-members on the issues associated with moving away from lead shot during visits to sites across the UK. To date, BASC has run 25 sustainable ammunition education and training days (350 attendees), published a blog and distributed pamphlets on the issue, along with guidance and stories on its website and via social media. The phasing out of lead shotgun ammunition has also been covered by articles in other shooting magazines and in items on Field Sports TV and videos on YouTube. GWCT followed up the joint statement by including three talks on the issue at their virtual annual conference: ballistics of alternative ammunition types; the Danish experience with nonlead shot after a statutory ban on lead shotgun ammunition in 1996; and food retailer Waitrose's plans for transition to selling only game meat products from animals killed using non-lead ammunition. The last presentation (GWCT 2020) was viewed over 300 times on the GWCT website by January 2021. GWCT also featured items and articles on this topic in its newsletters and other publications distributed to members. There may have been other promotional activities by these and other organisations that we have overlooked and planned additional promotional activities of which we do not have details.

Items published by shooting and rural organisations who signed the joint declaration were generally positive about a voluntary transition to non-lead shotgun ammunition and gave accurate 
information about practical aspects of the change. However, some of the nine signatory organisations requesting the voluntary transition to non-lead gunshot also made it clear that they continued to oppose any new regulations on the use of lead ammunition. We suggest that this might confuse the message being sent to shooters and others. For example, in 2020 BASC supported its European hunting partners to fight legislation to further restrict the use of lead ammunition in and around wetlands across the European Union (EU). The restrictions ban possession and use of lead shotgun ammunition while shooting over, or within $100 \mathrm{~m}$ of, temporary and permanent wetlands, as defined by the Ramsar Convention, which extends the regulations currently in place in UK countries. Even though BASC encourages its members to comply with UK regulations on the use of lead shotgun ammunition in wetlands or for shooting waterfowl, BASC's Head of Policy and Campaigns said of the EU proposals, "BASC opposes these proposals as being overly restrictive and precautionary and we are working hard to see them significantly dampened" (BASC 2020b). Other organisations, including the Countryside Alliance, also opposed the introduction of such regulations in the UK (Countryside Alliance 2020). While the EU restrictions have now been adopted and published (European Union 2021), there is no legal requirement to implement them in Britain as they were formally adopted a few weeks after the end of the transition period of the UK's exit from the EU.

\section{CONSEQUENCES}

\section{Sampling of pheasants}

Dead pheasants were purchased from retailers or obtained directly from shoots by 17 sets of coworkers, who were the principal investigators (REG, DJP and MAT) or individuals or couples known to them. These co-workers are co-authors on this paper or are listed in the Acknowledgements and were selected to achieve wide geographical coverage of Britain. Co-workers were asked to obtain pheasants from sources dispersed as widely as possible in the area where they lived. Where possible, co-workers asked the supplier where the birds had been shot. We obtained 276 whole birds or oven-ready prepared carcasses from which the viscera (guts), legs, head and neck had been removed. At least one shot and/or shot fragment was recovered from 180 of these pheasants; these had been obtained from 73 businesses. Numbers of birds from which at least one shot and/or shot fragment was recovered were obtained from the following types of source, with the number of birds from each source type being followed by the number of businesses in square brackets: butcher's shops $(n=86$ [47]), fishmonger $(n=1[1])$, farm shops $(n=7[5])$, game dealers $(n$ $=24[10])$, direct from shoots $(n=5[2])$, mail order $(n=21[6]), 10$ different Waitrose stores $(n=33$ [1]) and another supermarket ( $n=3[1])$.

Additional effort was made to purchase pheasants from the Waitrose \& Partners supermarket chain because, in 2019, Waitrose announced its intention to sell only game shot using non-lead ammunition from the 2020/2021 shooting season onwards (Barkham 2019). Waitrose wishes the shot types used to kill pheasants sold in their stores to be monitored, so we reported results from these separately from those obtained from other sources. Waitrose indicated before the 2020/2021 shooting season began that it would not be possible to supply game shot only using non-lead ammunition because few of the retailer's dedicated estates were shooting as a result of the COVID-19 pandemic. Therefore, Waitrose deferred their target date to the 2021/2022 season (Waitrose 2020).

We assigned each sampled pheasant to one of the 11 Nomenclature of Territorial Units for Statistics (NUTS) regions of Britain, which comprise Scotland, Wales and nine English regions (Office for National Statistics 2020). This assignment was based upon information on where it had been shot (156 birds) or, where this was lacking, by assuming that it had been shot in the same region as the location of the supplier ( 24 birds). To present the results, we grouped the nine English NUTS regions into three larger categories: Northern England (comprising North East, North West and Yorkshire $\&$ the Humber); Central England (East Midlands, West Midlands and East of England); and Southern England (London, South East and South West). The pheasants obtained from Waitrose stores were placed in a separate category. All Waitrose pheasants were obtained from shoots in the Central England region (J. Gregson, Communications Manager, Corporate Social Responsibility, Health and Agriculture, Waitrose \& Partners, personal communication).

\section{Extracting shotgun pellets from pheasant carcasses}

Co-workers skinned each pheasant carcass and checked for shotgun pellets adhering to the inner surface of the skin or to the surface of the body. They then dissected the carcass and searched for pellets, or fragments thereof, embedded in the tissues (Figure 1). Co-workers were not asked to attempt to recover all of the pellets in the carcass, only to try to collect at least one pellet. However, many birds were examined exhaustively and the maximum number of pellets recovered from one bird was 12 . No pellets were recovered from $35 \%$ of the birds examined. This was expected, based upon a previous Xradiography study of pheasant carcasses purchased in Britain (Pain et al. 2010) in which no shotgun pellets were detected on X-rays of $45 \%$ of birds, though most of those without pellets were known to have been shot. We assume that the shot that killed these birds had either passed through the body or had lodged in the head, wings or viscera, which were discarded during carcass preparation. Co-workers collected a total of 409 pellets and 7 fragments, which were washed and dried. Both pellets and fragments were recovered from five birds and one large fragment alone was recovered from another bird. All the pellets and fragments collected from 
each bird were placed in a screw-topped polyethylene tube marked with a unique code.
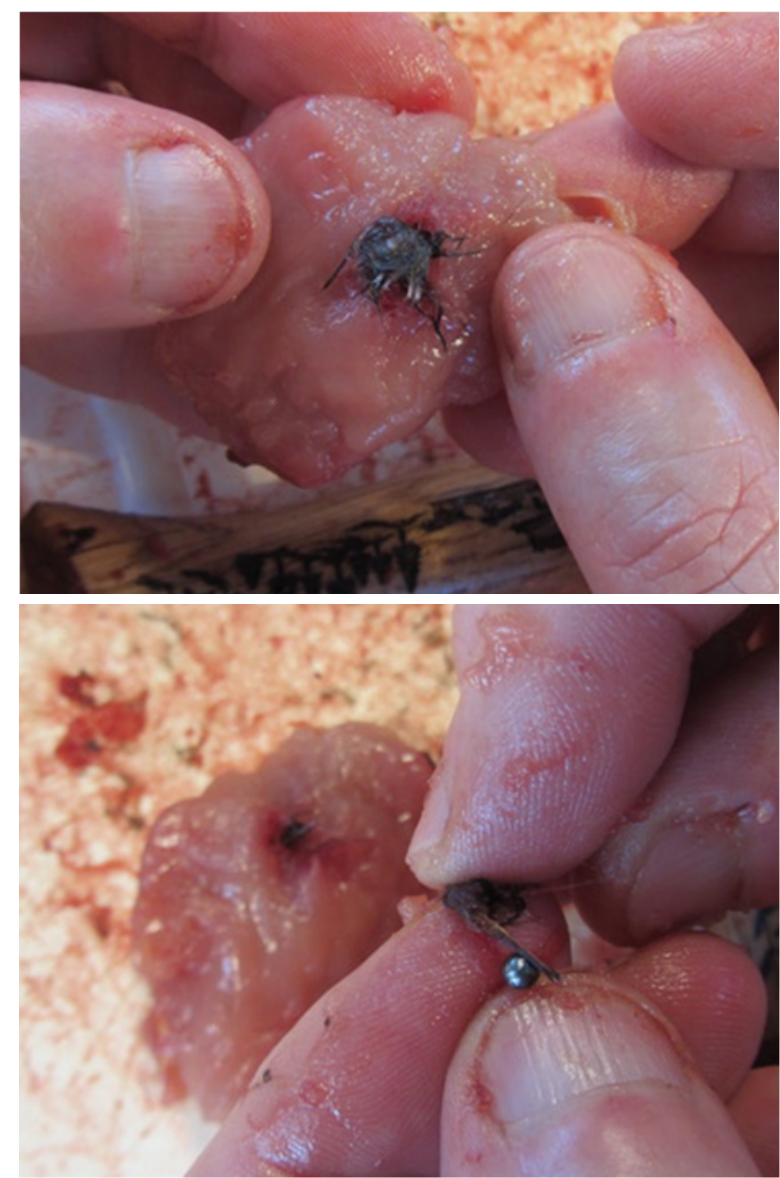

Figure 1. A piece of pectoral muscle from a wildshot common pheasant showing (top) an embedded ball of feathers detected as a hard nodule within the piece of muscle and (bottom) the ball of feathers removed and the shot within it taken out. Shot were also frequently found immediately under the skin.

\section{Qualitative examination and selection of shotgun pellets}

Laboratory examination and chemical analysis of shotgun pellet samples were conducted at the Environmental Research Institute, University of the Highlands and Islands, Thurso, UK, by one researcher (MAT), who did not have access to data about the sources from which pheasants had been obtained. We first conducted a qualitative assessment to determine whether shotgun pellets recovered from each pheasant were all of the same type or of different types. We used the approach of Kanstrup \& Balsby (2019), who used physical deformation upon compression (lead shot - easily deformable; iron - not deformable; bismuth brittle) and attraction to a magnet (lead and bismuth - non-magnetic; iron - magnetic) for their qualitative tests of pellet types recovered from pheasant and mallard Anas platyrhynchos carcasses in Denmark. All of our recovered shotgun pellets and suspected fragments of shot were weighed individually and subjected to an assessment comprising: (1) a description of surface colour; (2) testing of deformability/brittleness by hand, using a pair of pliers; and (3) testing whether the pellet was attracted to a magnet. Where more than one shotgun pellet was recovered from the same pheasant $(n=93$ pheasants), the pellet weights and qualitative tests indicated that all pellets from the same bird were of the same type in all cases except for one. For this bird, one of four pellets recovered was attracted to a magnet and could not be deformed using pliers and the other three were not magnetic and were deformed. In this case, we prepared the magnetic pellet and one of the others, selected at random, for separate chemical analysis. For all of the other pheasants, we prepared the only pellet or fragment recovered for analysis $(n=87)$ or prepared one pellet, selected at random, where there were two or more pellets $(n=92)$.

\section{Identification of the principal chemical element in shotgun pellets}

Each shot was weighed to $\pm 0.001 \mathrm{~g}$ and placed in a $50 \mathrm{ml}$ digestion tube to which $5 \mathrm{ml}$ of concentrated ultra-trace metal grade nitric acid was added. Tubes were then kept for approximately one week at room temperature. Most pellets appeared to dissolve during this time and most left only a white precipitate. The volume of liquid in the tube was then made up to $20 \mathrm{ml}$ with Milli-Q Type I water. Tubes were vortex mixed, left overnight to allow the white precipitate to re-dissolve, then vortex mixed again, and the volume made up to $50 \mathrm{ml}$. In one case, a pellet that had been noted as magnetic previously did not entirely dissolve, and in eight other cases one or more small but visible particles remained undissolved. All other digests were entirely free of particulates and complete dissolution had occurred. The solutions were then serially diluted and analysed using an Inductively Coupled Plasma Atomic Emission Spectrometer (ICP-AES; Varian 720 ES with SPS3 autosampler). Based upon the types of ammunition known to be available in Europe, the instrument was calibrated to quantify concentrations of lead, tungsten, bismuth, iron and copper (Kanstrup \& Thomas 2019). Lead pellets coated with a thin layer of copper are also sold, but lead is the principal element in these pellets. The composition by mass of these elements in each pellet was estimated and expressed as a proportion (\%) of the initial mass of the pellet. Where some of the pellet had not dissolved, this was noted and taken into account when interpreting bulk primary composition. Where copper comprised a small but notable proportion $(>0.5 \%)$ of pellet mass, this was recorded. However, further analyses to quantify elements present at low proportions in the shot were not made as this would have required further analysis using low dilution samples, which was considered unnecessary given the aims of this study. Pellet composition in \% of bulk terms was classified according to the most abundant of the above elements detected. These methods (qualitative and quantitative) were also tested on shotgun pellets of known advertised composition, containing each of these principal metallic elements, for reference purposes. 
Principal chemical element in shotgun pellets collected from pheasants in the 2020/2021 shooting season

Lead comprised $>50 \%$ of the initial mass of pellets recovered from 179 of the 180 pheasants (99.4\%), and exceeded 90\% for pellets from 177 birds $(98.3 \%)$. For one pellet with $71 \%$ lead, some visible undissolved material was still present in the digestion tube. The proportion of lead for a second pellet was $85 \%$. All of these 179 pellets were also deformable using pliers and not attracted to a magnet. Tungsten, bismuth or iron comprised $<5 \%$ of the mass of all pellets principally composed of lead. Copper was estimated to comprise $>0.5 \%$ of mass in six pellets principally composed of lead, five of which had been recorded as being coppercoloured before being dissolved. None of the pellets principally composed of lead with estimated $<0.5 \%$ copper were described as copper-coloured. The pellets with $>0.5 \%$ copper are likely to have come from shotgun cartridges containing lead pellets coated with a thin layer of copper.

Iron comprised $>50 \%$ of the initial pellet mass, and was therefore the principal chemical element, in pellets recovered from two of the 180 pheasants $(1.1 \%)$. The proportions of the mass of these two pellets composed of iron were $61 \%$ and $100 \%$. The pellet with the lower iron value was only partially dissolved. Neither of these pellets could be deformed using pliers and both were attracted to a magnet. None of the other metals occurred in these pellets at detectable levels. One of the two birds with iron-based shot had a total of nine shot recovered, all of which had similar qualitative characteristics. The other bird, which was purchased from a Waitrose supermarket, had one iron-based shot and three other shot, characterised as principally composed of lead. No pellets were found to be composed principally of tungsten, bismuth or copper. Pellets composed principally of lead predominated in all of the countries and regions sampled (Table 1).

\section{Comparison between results obtained in the} 2008/2009 and 2020/2021 shooting seasons

The only previous study of which we are aware where the shot types used to kill pheasants and other non-wetland birds in the UK were identified is that of Pain et al. (2010). Those authors used qualitative methods to identify the principal chemical elements in shotgun pellets recovered from carcasses of five species of wild-shot, non-wetland gamebirds purchased from supermarkets, game dealers, butchers, and directly from gamebird shoots in England, Scotland and Wales in the 2008/2009 shooting season. The species sampled were common pheasant, red-legged partridge Alectoris rufa, common wood pigeon Columba palumbus, red grouse Lagopus lagopus and Eurasian woodcock Scolopax rusticola. These species comprise the most frequently shot non-wetland gamebird species in the UK (PACEC 2014). In total, shotgun pellets were recovered and tested from 30 individuals of all of these species combined. None of the shot was magnetic, indicating that no iron or steel shot were present in the sample. Shot from one partridge was of an indeterminate type but may have been lead. All of the other shot were composed primarily of lead, including those from all 10 of the pheasants in the sample. These results indicate that the vast majority of non-wetland gamebirds shot in Britain, including pheasants, were killed using lead shotgun ammunition 12 years before the joint statement was issued in 2020. Our results from the larger sample of pheasants obtained in the 2020/2021 shooting season, which began seven months after the joint statement, indicate that the vast majority of pheasants shot in Britain continued to be killed using lead ammunition (Table 1; Table 2). We conclude that efforts to persuade pheasant shooters to use nonlead ammunition have not yet had any detectable effect on the types of ammunition they use.

Table 1. Numbers of common pheasants obtained in Britain in the 2020/2021 shooting season for which the principal element in a shotgun pellet was identified as one of five elements. Results are shown according to the source of the bird (country or region in which the bird was most likely to have been shot or a Waitrose supermarket). One pellet was analysed from each bird, ${ }^{\S}$ except for one bird from a Waitrose supermarket from which one iron-based and one of three lead-based pellets were analysed.

\begin{tabular}{lcccccc}
\hline & \multicolumn{7}{c}{$\begin{array}{c}\text { Number of birds with a pellet } \\
\text { composed principally of this element } \\
\text { Source }\end{array}$} & Lead & Tungsten & Bismuth & Iron & Copper & $\begin{array}{c}\text { Total } \\
\text { birds }\end{array}$ \\
\hline Southern England & 49 & 0 & 0 & 0 & 0 & 49 \\
Central England & 28 & 0 & 0 & 0 & 0 & 28 \\
Northern England & 24 & 0 & 0 & 0 & 0 & 24 \\
Scotland & 35 & 0 & 0 & 1 & 0 & 36 \\
Wales & 10 & 0 & 0 & 0 & 0 & 10 \\
Waitrose & 33 & 0 & 0 & 1 & 0 & $33^{\S}$ \\
Total & 179 & 0 & 0 & 2 & 0 & 180 \\
\hline
\end{tabular}


Table 2. Comparison of the estimated percentage of wild-shot non-wetland gamebirds killed using lead shotgun ammunition in Britain between a study conducted in the 2008/2009 shooting season (Pain et al. 2010) and the present study, which was conducted in the 2020/2021 shooting season. Results labelled 'All' are for five gamebird species combined (see text), including ten common pheasants, and are shown separately under the assumptions that a sampled bird with indeterminate shot type was ${ }^{\mathrm{a}}$ or was not ${ }^{\mathrm{b}}$ killed using lead shot. 95\% Clopper-Pearson confidence intervals (CL; Clopper \& Pearson 1934) are shown for each estimated percentage.

\begin{tabular}{lcccccc}
\hline Species & Period & $\begin{array}{c}\text { Number } \\
\text { tested }\end{array}$ & $\begin{array}{c}\text { Number } \\
\text { principally } \\
\text { lead }\end{array}$ & Estimate & $\begin{array}{c}\text { Lower } \\
\text { CL }\end{array}$ & $\begin{array}{c}\text { Ppper } \\
\text { CL }\end{array}$ \\
\hline All $^{\mathrm{a}}$ & $2008 / 2009$ & 30 & 30 & 100.0 & 88.4 & 100.0 \\
All & $2008 / 2009$ & 30 & 29 & 96.7 & 82.8 & 99.9 \\
Pheasant & $2008 / 2009$ & 10 & 10 & 100.0 & 69.2 & 100.0 \\
Pheasant & $2020 / 2021$ & 180 & 179 & 99.4 & 96.9 & 99.9 \\
\hline
\end{tabular}

\section{DISCUSSION}

A review of the performance of voluntary approaches to the control of a wide range of environmental and human health problems indicated that the majority of them produced poor results (McCarthy \& Morling 2015). Previous attempts to phase out the use of lead shotgun ammunition in the UK by voluntary means have been unsuccessful (Stroud 2015), although a recent study suggests that an 'open to change' perspective exists within the British shooting community (Newth et al. 2019). An online questionnaire survey conducted by the GWCT early in 2020 found that $53 \%$ of about 4,000 respondents wished to switch away from lead ammunition, with $47 \%$ wishing to continue to use lead (Gilruth 2020). However, our evidence suggests that there has been no detectable progress, so far, in making the voluntary transition from lead to nonlead shotgun ammunition envisaged by the nine UK shooting and rural organisations in February 2020. This leads us to compare this early outcome with the degree of success of longer-term efforts to achieve voluntary changes in ammunition use elsewhere. Examination of the factors associated with compliance with such efforts may help to explain the current low level of acceptance of non-lead gunshot for pheasant shooting in Britain indicated by our data.

There have been numerous efforts to promote voluntary abstention by hunters from the use of lead bullets and shotgun ammunition in the USA. One of the most successful documented examples was reported by Sieg et al. (2009) who described activities undertaken between 2003 and 2007 by the Arizona Game and Fish Department to encourage voluntary use of non-lead ammunition in part of the range of the California condor Gymnogyps californianus, a species vulnerable to poisoning from ingested lead projectile remnants in unrecovered shot animals and discarded viscera. An education campaign began in Arizona in 2003 to promote the use of non-lead (principally copper) bullets by hunters of deer and other large game. In
2005 and 2006, non-lead ammunition was provided free. The resulting 50-60\% voluntary participation by deer hunters was considered insufficient to reduce the condors' exposure to lead enough to allow the population to be self-sustaining. Increased efforts in 2007 included improved hunter engagement activities through articles in sport shooting publications and other educational materials, and incentives for retrieving and disposing of viscera from shot deer instead of leaving them in the field. The programme used social psychology and marketing principles to aid its design, and incorporated lessons learnt from previous similar voluntary programmes. Voluntary hunter compliance increased to $80 \%$. Monitoring of exposure to lead of satellite-tagged condors by repeated measurements of the concentration of lead in their blood indicated that exposure to lead was high during the hunting season for birds that foraged in areas where deer hunting was prevalent, but that there was a marked reduction in exposure to lead in the area of Arizona covered by the education campaign, compared with birds visiting other deerhunting areas, mostly in Utah, that lacked such programmes (Green et al. 2008). It was concluded that these educational and awareness-raising efforts were locally successful but needed to be extended to cover more of the foraging range of the condor population to allow it to become self-sustaining.

Efforts to promote voluntary abstention from the use of lead ammunition have not all been as successful as the California condor example and comparisons among them suggest some features associated with success. Schulz et al. (2021) explored attitudes and experiences of United States Fish and Wildlife Service staff who had implemented outreach and voluntary non-lead ammunition-use programmes more widely in the USA. Combining the results of their study with those of Sieg et al. (2009) and other published literature on voluntary schemes, we suggest that there are ten important components of voluntary programmes that will help increase uptake: 
(1) Effective audience analysis and targeting including different sectors of the hunting community, governmental and non-governmental agencies, ammunition manufacturers, dealers and the media; (2) authoritative and trusted spokespeople - particularly leaders of change in hunting and sports groups and ammunition retailers; (3) commitment to multi-year programmes; (4) consistent messaging by all interested parties, making cross-sectoral working important; (5) effective compliance monitoring; (6) incentives and reciprocity, such as provision of free or reduced-cost ammunition; (7) social proof - illustrating that others are also participating; (8) positive feedback thanking participants for their help and highlighting the benefits; (9) authority - active engagement by influencing and management agencies, including governmental agencies; (10) disincentives for continued lead ammunition use - such as an indication that regulation will follow if compliance is inadequate. The first four of these factors, and some components of the others, are associated with education. Sieg et al. (2009) also noted the value of focus groups to develop and refine messages and of marketing professionals to help tailor messages.

The actions undertaken so far in the UK, and described above in the ACTION section, can be compared with the ten elements of successful voluntary campaigns to phase out lead ammunition in the USA. Some UK shooting and rural organisations have begun to implement the educational activities on the list, but they may need to be expanded and taken up more widely by all of the organisations participating in the joint statement. Several of the other elements may also require more attention. In particular, we suggest that there is a problem with consistency of messaging (element 4 above), arising from the opposition of some of the organisations to regulation.

The failure to achieve compliance with existing waterfowl shooting regulations in England, compliance with which is supported by the shooting and rural organisations, suggests that implementing voluntary change will not be simple, especially if some messages delivered in the media are negative (Cromie et al. 2015). Sieg et al. (2009) noted that a single negative media article can prevent acceptance of a fact-based education strategy. This may contribute to the general vulnerability of voluntary approaches documented by McCarthy \& Morling (2015). Carefully designed and consistent messaging is therefore likely to be essential if shooting and rural organisations are to be successful in effecting change.

Although the Waitrose supermarket chain announced in 2019 its intention to sell only game shot using non-lead ammunition from the 2020/2021 shooting season onwards (Barkham 2019), they indicated before the 2020/2021 shooting season began that this would not be possible because of the COVID-19 pandemic. They therefore deferred their target date until the 2021/2022 season (Waitrose 2020). All of the pheasants we purchased from ten
Waitrose stores in the 2020/2021 season had been shot using lead shotgun ammunition, although one iron-based pellet was recovered from one bird, along with three lead-based pellets.

The intended voluntary transition from lead to non-lead shotgun ammunition is at an early stage and has not yet progressed even one-fifth of the way to successful completion. Because of the range of benefits of use of non-lead ammunition to the environment, human health and protection of game markets in the UK and Europe (Arnemo et al. 2019), it is possible that regulation of lead gunshot ammunition will be introduced in the UK in advance of the proposed five-year voluntary lead shot phaseout period. Whether that happens or not, we plan to continue monitoring shot types used for pheasant shooting annually until the 2024/2025 shooting season, when the shooting and rural organisations envisage that the use of lead shotgun ammunition will have ended.

\section{ACKNOWLEDGEMENTS}

We thank Graeme Buchanan, Jacquie Clark, Stephen Dodd, Sophie Green, Shireen Green, James Silvey, Matthew Webster, Nick Wilkinson, Alastair M. Wilson, and Jeremy Wilson for assistance with obtaining and processing the pheasant carcasses. We are grateful to Niels Kanstrup and John Swift, who supplied us with shotgun pellets of known types to test our chemical analysis methods. Peter Marshall (BASC) and Teresa Dent (GWCT) kindly provided information on the efforts made by their organisations to promote the transition to non-lead shotgun ammunition. We thank Ann Thornton, Bill Sutherland and three anonymous reviewers for useful comments. The Royal Society for the Protection of Birds, Waitrose \& Partners and Lincolnshire Game contributed to the costs of materials and reagents for the study.

This paper is the first publication of results of the SHOT-SWITCH project. More information on the objectives and methods of the project are available on the website of the Environmental Research Institute, University of the Highlands and Islands, Thurso, UK at: https://eri.ac.uk/research/majorprojects/shot-switch/ 


\section{REFERENCES}

Arnemo, J.M., Cromie, R., Fox, A.D. Kanstrup, N., Mateo, R., Pain, D.J., \& Thomas, V.G. (2019). Transition to lead-free ammunition benefits all. Ambio, 48, 1097-1098.

Barkham, P. (2019) Waitrose stops sale of birds shot with lead as experts call for UK ban. The Guardian online. https://www.theguardian.com/business/2019/jul /29/experts-call-for-ban-on-lead-shot-aswaitrose-overhauls-sale-of-game

BASC (2020a) A joint statement on the future of shotgun ammunition for live quarry shooting. https://basc.org.uk/a-joint-statement-on-thefuture-of-shotgun-ammunition-for-live-quarryshooting

BASC (2020b) BASC fights EU lead ammunition restrictions. https://basc.org.uk/basc-fights-eulead-ammunition-restrictions

Clopper, C. \& Pearson, E.S. (1934). The use of confidence or fiducial limits illustrated in the case of the binomial. Biometrika, 26, 404-413.

Cromie, R., Newth, J., Reeves, J., O'Brien, M., Beckmann, K \& Brown, M. (2015) The sociological and political aspects of reducing lead poisoning from ammunition in the UK: why the transition to non-toxic ammunition is so difficult. Pages 104-124 in: R.J. Delahay \& C.J. Spray (eds.) Proceedings of the Oxford Lead Symposium. Lead Ammunition: understanding and minimising the risks to human and environmental health. Edward Grey Institute, University of Oxford, Oxford, UK.

Countryside Alliance (2020) EU vote to ban lead shot over wetlands. https://www.countrysidealliance.org/news/2020/9/eu-vote-to-ban-leadshot-over-wetlands

DEFRA (2020) Letter to Mr David A. Stroud from the Ministerial Contact Unit. 16 October 2020.

European Union (2021) Commission Regulation (EU) 2021/57. Official Journal of the European Union. https://eur-lex.europa.eu/legalcontent/EN/TXT/PDF/?uri=CELEX:32021R00 $57 \&$ from $=\mathrm{EN}$

Green, R.E. \& Pain, D.J. (2019) Risks to human health from ammunition-derived lead in Europe. Ambio, 48, 954-968.

Gilruth, A. (2020) Lead shot: what did you tell us? https://www.gwct.org.uk/blogs/news/2020/febr uary/lead-shot-what-did-you-tell-us

Green, R.E., Hunt, W.G., Parish, C.N. \& Newton, I. (2008) Effectiveness of action to reduce exposure of free-ranging California condors in Arizona and Utah to lead from spent ammunition. PLoS ONE, 3, e4022.

GWCT (2020) Waitrose- our stance on lead shot. https://www.gwct.org.uk/blogs/news/2020/octo ber/video-waitrose-\%E2\%80\%93-our-stanceon-lead-shot/ (accessed 23 February 2021)

Kanstrup, N. \& Balsby, T.J.S. (2019) Danish pheasant and mallard hunters comply with the lead shot ban. Ambio, 48, 1009-1014.
Kanstrup, N. \& Thomas, V.G. (2019) Availability and prices of non-lead gunshot cartridges in the European retail market. Ambio, 48, 1039-1043.

Mateo, R. \& Kanstrup, N. (2019). Regulations on lead ammunition adopted in Europe and evidence of compliance. Ambio, 48, 989-998.

McCarthy, D. \& Morling, P. (2015). Using Regulation as a Last Resort: Assessing the Performance of Voluntary Approaches. Royal Society for the Protection of Birds: Sandy, Bedfordshire, UK.

National Audit Office (2014) Using alternatives to regulation to achieve policy objectives. Paper by the National Audit Office, London, UK.

Newth, J.L., Lawrence, A., Cromie, R.L., Swift, J.A., Rees, E.C., Wood, K.A., Strong, E.A., Reeves, J. \& McDonald, R.A. (2019) Perspectives of ammunition users on the use of lead ammunition and its potential impacts on wildlife and humans. People and Nature, 1, 347361.

Office for National Statistics (2020) Eurostat: An overview of the 3 NUTS and 2 LAU layers in the UK.

https://www.ons.gov.uk/methodology/geograph y/ukgeographies/eurostat

PACEC (2014) The Value of Shooting. The economic, environmental, and social benefits of shooting sports in the UK. An independent survey report prepared by PACEC (Public and Corporate Economic Consultants) on behalf of UK shooting and countryside organisations. Public and Corporate Economic Consultants report.

Pain, D.J., Cromie, R.L., Newth, J., Brown, M.J., Crutcher, E., Hardman, P., Hurst, L., Mateo, R., Meharg, A.A., Moran, A.C., Raab, A., Taggart, M.A. \& Green R.E. (2010) Potential Hazard to Human Health from Exposure to Fragments of Lead Bullets and Shot in the Tissues of Game Animals. PLoS ONE, 5, e10315.

Pain, D.J., Mateo, R. \& Green, R.E. (2019) Effects of lead from ammunition on birds and other wildlife; A review and update. Ambio, 48, 935953.

Schulz, J.H., Wilhelm Stanis, S.A., Hall, D.M. \& Webb, E.B. (2021) Until it's a regulation it's not my fight: Complexities of a voluntary non-lead hunting ammunition program. Journal of Environmental Management, 277, 111438.

Sieg, R., Sullivan, K.A. \& Parish, C.N. (2009) Voluntary lead reduction efforts within the northern Arizona range of the California Condor. Pages 341-349 in: R. T. Watson, M. Fuller, M. Pokras \& W. G. Hunt (eds.) Ingestion of Lead from Spent Ammunition: Implications for Wildlife and Humans. The Peregrine Fund, Boise, Idaho, USA.

Stroud, D.A. (2015) Regulation of some sources of lead poisoning: a brief review. Pages 8-26 in: R.J. Delahay \& C.J. Spray (eds.) Proceedings of the Oxford Lead Symposium. Lead Ammunition: understanding and minimising the risks to 
human and environmental health. Edward Grey Institute, University of Oxford, Oxford, UK.

Taggart, M.A., Shore, R.F., Pain, D.J., Peniche, G., Martinez-Haro, M., Mateo, R., Homann, J., Raab, A., Feldmann, J., Lawlor, A.J., Potter, E.D., Walker, L.E., Braidwood, D.W., French, A.S., Parry-Jones, J., Swift, J.A. \& Green, R.E. (2020) Concentration and origin of lead $(\mathrm{Pb})$ in liver and bone of Eurasian buzzards (Buteo buteo) in the United Kingdom. Environmental Pollution, 267, 115629.

Waitrose (2020) Animal Welfare: Lead Shot Pledge https://www.waitrose.com/home/inspiration/abo ut_waitrose/the_waitrose_way/waitrose_animal _welfarecommitments.html (accessed 6 January 2021)

The Conservation Evidence Journal is an open access online journal devoted to publishing the evidence on the effectiveness of management interventions. The other papers from The Conservation Evidence Journal are available from

www.conservationevidencejournal.com. The pdf is free to circulate or add to other websites and is licensed under the Creative Commons Attribution 4.0 International License http://creativecommons.org/licenses/by/4.0/. Under this licence, authors retain ownership of the copyright for their articles. 